\title{
Determination of the Elemental Concentration of Kiln Feed and Cement Factory Dusts using Instrumental Neutron Activation Analysis
}

\author{
B. M. Wufem* ${ }^{1}$, H.M. Maina ${ }^{2}$, O. N. Maitera ${ }^{2}$ \\ ${ }^{1}$ Chemistry Department, Plateau State University Bokkos, PMB 2012 Jos, Nigeria \\ ${ }^{2}$ Chemistry Department, Modibbo Adama University of Technology Yola, Nigeria
}

\begin{abstract}
The concentration of elements in cement factory dust and kiln feed dust were determined using Instrumental neutron activation analysis at the Nigerian Research reactor -1 (NIRR-1). The kiln feed and cement dusts showed the presence of 31 and 29 elements respectively and the order in which they occur in both dusts were $\mathrm{Ca}>\mathrm{Al}>\mathrm{Fe}>\mathrm{K}>\mathrm{Mg}>\mathrm{Ti}>\mathrm{Mn}>\mathrm{Na}>\mathrm{Ba}>\mathrm{Rb}>\mathrm{Rb}>\mathrm{Cr}>\mathrm{La}>\mathrm{Nd}>\mathrm{V}>\mathrm{Zn}>\mathrm{Th}>\mathrm{Co}>$ $\mathrm{Sm}>\mathrm{Sc}>\mathrm{Hf}>\mathrm{As}>\mathrm{Dy}>\mathrm{Cs}>\mathrm{U}>\mathrm{Yb}>\mathrm{Eu}>\mathrm{Br}>\mathrm{Ho}>\mathrm{Lu}>\mathrm{Hg}=\mathrm{Sb}$. Their levels are higher than international Standard limits for dust. Bivariate Pearson correlation for the elemental contents of the cement dust and Kiln feed dust showed calcium, Titanium, Vanadium, Cobalt, Dysprosium and Holmium, to be positively correlated $(<0.01)$ while it is negatively correlated with $\mathrm{Al}$ and $M n$. The presence of these elements in sizes that can be raised by wind is of serious concern to the environment as continuous inhalation or ingestion of the dust may accumulate these elements in human and animal systems. Such elements, some of which are toxic, may pose serious potential health hazards to the occupational staff or residents scattered around the industry. This research reveals that the cement work environment could be loaded with particulates that contain elements that may constitutemajor health hazards to Plant, animal and human lives around the vicinity of the factory.
\end{abstract}

Keywords: Cement dust, Kiln dust, health hazards, Toxic elements, NAA.

\section{Introduction}

The emission of dust into the atmosphere from natural and human activities can be devastating to the environment. It constitutes a serious pollutant to man, animal and plants. Dust consists of solid matter in such a fine state of subdivision that the particles are small enough to be raised and carried by wind (Farmer, 1993). As a result of its fine particle size it travels over long distances and the total suspended particulate matter in the atmosphere is thus increased. As such its implications on humans, animals and plants can be hazardous. Various industrial processes generate huge amount of dusts (Hirano et al., 1995) and Cement production process has been known to produce tremendous amount of dust which escapes into the environment travelling long distances over which they are deposited, depending on particle size, emission rates and meteorology (Farmer, 1993). The impact of dust deposition can be variable depending on the dust type and size, dust composition, wind direction and intensity, and contact surface. For instance,Toxic compounds such as fluoride, magnesium, lead, zinc, copper, beryllium, sulphuric acid and hydrochloric acid were found to be emitted by a cement manufacturing plant (Andrej, 1987) and this may cause the abrasion and wear to machinery in the industry and so is Suspended mill and mine dust can cause explosion (NSI and Shallsuku, 2002). Presence of particulate matter in the atmosphere may affect visibility and may significantly add to air pollution (Aidid and Chadhar, 1990). Kusaka et al., (1986) reported that heavy metal dusts caused asthma and bronchial obstruction in rats exposed to air pollutants for six months. Yoshiaki et al. (1986) reported reduction in sensitivity of rats exposed to dust. Volkavic (1975) showed a direct correlation between the period of high air pollution and excess death of increased rates of hospital admissions in the exposed population. It causes imbalances of the environment and produces air pollution hazards (Niragau and Davidson, 1986). Several studies have demonstrated linkages between cement dust exposure, chronic impairment of lung function and respiratory symptoms in human population. Cement dust irritates the skin, the mucous membrane of the eyes and the respiratory system. Hazards arising from breathing of free silica $\left(\mathrm{SiO}_{2}\right)$ in mining, quarrying, ceramic and abrasive industries result in chronic lung ailments (Nsi and Shallsuku, 2002). Its deposition in the respiratory tract causes a basic reaction leading to increased $\mathrm{pH}$ values that irritates the exposed mucous membranes (Zeleke et al. 2010). A study to evaluate the mutagenic effect of occupational exposure to cement dust in some workers concluded that the chromosomal damage was more pronounced in the workers who are also smokers when compared with the non - smokers both in the control and exposed group (Fatima et al. 2001). Cement dust inhalation causes silicosis and respiratory disorders (Barziv and Golberg, 1974; Warrell et al., 1975). 
A typical major elemental composition of Portland cement is $\mathrm{CaO} 64 \%, \mathrm{SiO}^{2} 21 \%, \mathrm{Al}_{2} \mathrm{O}_{3} 5.8 \%, \mathrm{MgO}$ 2.5, $\mathrm{SO}_{2}$ 1.7, $\mathrm{Cr}$ (VI) $0.002 \%$ and alkali oxides $1.4 \%$ (Winder and Carmody, 2002). However the elemental content mayvary depending on thesource of raw materials. The determination of elements in cement and geological samples enjoy the use of many various techniques, such as AAS (Wufem et al., 2013), ICP-OES (Amira et al 2014), ICP-MS (Olowoyo et al 2015), XRF(Ibrahim et al., 2012, Addo et al., 2012) etc. Howver the use of Neutron activation analysis Methodhas the major advantages of havingrelative freedom from matrix effects and interferences,high accuracy and very low or zero blank contributions(Gladney, et al., 1987;Janghorbani, et al., 1980; Ni, etal., 1991;Win, 2004). For ultra-trace analysis this is an important advantage over such competing techniques AAS or ICP for which the sample must normally be in solution, thus introducing the potential for contamination from reagents and equipment and the loss of analyte through adsorption, volatilization, coprecipitation, etc. Element sensitivities vary from $10^{-3}$ to $10^{-10}$ grams per gram of sample and accuracy is usually between two and ten percent of the reported value, depending on the element analyzed and its concentration in the sample (Win, 2004). The detection limit for a particular element depends upon the measured count rate $(R)$ of the gamma ray being monitored and the background radiation.

Several studies on the determination of elements have been linked to the use of Neutron activation analysis (Ali-Abdallah et al., 2011; Kolesov and Shubina, 2003; Levi, 1996). Neutron activation analysis is one of the most powerful analytical technique for the quantitative and qualitative analysis of elements in geological, biological, industrial, atmospheric samples. It is a versatile method for various analytical problems due to its simplicity, multielement capacity, and sensitivity. Normally, the elements to be determined in a sample are made radioactive by irradiating the sample with neutrons. The number of detected $\gamma$-rays of a particular energy is directly proportional to the disintegration rate of the radionuclide, which in turn is directly proportional to the amount of parent isotope in the sample and can be determined by using the absolute method (Kafala and Macmahon 2007. NAA has been applied for determining many elements usually trace elements in Archaeology ( bone, ceramics, coins, glasses, painting, pottery, raw materials, soils and clays etc ), Biomedecine (blood, brain cell components breast tissue, cancerous tissues, drugs and medicines), Environmental science and related fields (aerosol, dust, fossil fuels and their ashes, birds, insects, fish, plants, trees, leaves), Forensics (explosive detection, paint, hair, shotgun pellets), Geology and geochemistry (asbestos, bore-hole samples, petroleum, rocks), Industrial products (alloys, fertilizers, fissile material detection, plastics, pharmaceutical products), Nutrition (food, food colours, grains, honey spices), and Quality Assurance of Analysis and Reference materials (IAEA 1998; Ehmann 1986) Determination of trace concentration of elements in cement dust is very useful in assessing their levels in inhalable materials in a cement work environment, evaluating the hazards to the cement producers and users as well as the environmental pollution. This work is therefore, aimed at evaluating the distribution of the elemental contents of cement dust and kiln feed dust in a cement factory environment.

\section{Study Area}

\section{Methodology}

Ashaka Cement Company was established in 1976 in Jalingo village of Bajoga Local Government Area of Gombe State, Nigeria. The company was established to meet the needs of construction works in the NorthEastern part of Nigeria. It has an installed capacity of 500,000 MT per annum (NSE, 2004). It is located in the Northern part of Gombe and lies between latitudes $10^{\circ} 45^{\prime} \mathrm{N}$ and $11^{\circ} 00^{\prime} \mathrm{N}$ and longitudes $11^{\circ} 15^{\prime} \mathrm{E}-11^{\circ} 30^{\prime} \mathrm{E}$ (Fig. 1). The company produces a huge amount of dust and gaseous pollutants to the environment. These constitute serious hazards to humankind and vegetation. Large proportions of the dust are deposited on farmlands and into the Gongola River, which may affect aquatic life. However, recently the emissions have been reduced tremendously with the installation of dust bag filters but, the effect may last a long time. The communities around the company are mostly peasant farmers. They practice subsidiary farming where maize, sorghum, millet, beans and ground nut are mostly cultivated. The farming practice is normally by shifting cultivation and mixed cropping

\section{Experimental}

In the preparation of reagents, chemicals of analytical grade and de-ionized distilled water were used, unless otherwise stated.

\section{Materials/Equipments}

The following materials and equipments were used during the course of this research: Cement dust, Kiln Feeds, human and animal blood, Animal lungs and Liver, Ceramic mortar, Desiccator, Plastic sample bottles, Sensitive balance, Beakers, Hot-air Oven, MNSR (Nirr-1), hyper-pure Germanium detector and associated counting facilities.

\section{Sampling}

Cement dust and Kiln Feeds dustCement dust was scraped from surfaces at different sites inside the factory. Collected samples were stored inside polythene bags with appropriate labeling and brought to the 
laboratory for analysis. Kiln Feed was collected in polythene bags at the raw material introduction point in the calcination chamber. and was taken to the laboratory for analysis.

\section{Sample pre-treatment}

Pre-treatment of Cement dust and Kiln feed dust

The dust samples were used without any processing since they were already in powdered form. Cement dust and Cement mixed raw materials (Kiln Feeds) was dried at $110^{\circ} \mathrm{C}$ for $24 \mathrm{hrs}$ in a temperature controlled oven according to the Methods of Kpeglo et al., (2012) to remove moisture. After moisture removal, the samples were cooled in a moisture-free atmosphere and pulverized into fine powdered form. Three replicate samples, about $100 \mathrm{mg}$ each, were weighed and sealed into polythene bags. Reference materials were also weighed and sealed into polythene bags for the quantitative analysis of the elements in the dust samples and for the validation of the analytical tool, respectively. The sealed bags were then packed into plastic rabbit capsules labeled by a marker, and heat sealed.

\section{Analytical Procedures}

Elemental compositions of all samples was analysed using Nigeria Research Reactor -1 at the Center for Energy Research and Training Zaria, ABU.

Irradiation and counting:

Samples and standard reference materials were irradiated in the inner pneumatic irradiation sites of the Nigeria research reactor, NIRR-1, using light water as moderator and coolant. The fuel source is highly enriched Uranium (90.2\%-Al alloy) with metal beryllium as reflectors. The reactor was cooled by natural convection. The samples were irradiated with a thermal flux of $5 \times 1011 \mathrm{ncm}-2 \mathrm{~s}-1$ when the reactor operated at half power of $15 \mathrm{Kw}$. Irradiation times ranged from $60 \mathrm{~s}$ to $6 \mathrm{~h}$ according to the half-lives of the elements of interest. The samples were analyzed using irradiation schemes by optimizing irradiation time, decay time and counting time based on the half-life of respective elements. After the irradiation, radioactivity measurements of induced radionuclides were performed by a PC-based x-ray spectrometry set-up. It consisted of an n-type high purity germanium (HPGe) detector coupled to a computer based Multi-channel Analyzer (MCA) mounted in a cylindrical lead shield (100 mm thick). Microsoft window based software (Winspan 2004) was used for the spectrum analysis. Validation of the technique for the experimental setup was carried out by irradiating a standard reference material for the same period of time as the samples, with comparator and the sample in the same location within the reactor.

\section{Data Analysis}

\section{Calculation of metal concentrations in samples:}

INAA is based on the nuclear reaction between neutrons and target nuclei of a sample material. It is a useful method for the simultaneous determination of a large number of major, minor and trace elements in ppbppm range without chemical separation (Cristache, et al., 2007). It is based on the the rate of formation of radioisotpe when sample is subjected to a neutron flux $\phi(\mathrm{E})$ (Hailu et al., 2013) and is expressed as:

$R=N o \int \phi(\mathrm{E}) \sigma(\mathrm{E}) f d E$

Where,

$N o=[m N A / A]$ is the number of target prior to irradiation,

$\sigma(E)=$ the reaction cross section for the Production of corresponding radio-isotopes,

$\mathrm{f}=$ the isotopic abundance of the target element,

$\mathrm{m}=$ the mass of the target,

$\mathrm{A}=$ the atomic weight of the target element and

$\mathrm{NA}=$ the Avogadro's number.

For a constant Energy of the flux, like thermal neutrons the equation becomes,

$R=[m N A / A] \phi(\mathrm{E}) \sigma(\mathrm{E}) f$

The number of radio-isotopes decaying in the time interval between the end of irradiation and the end of counting is;

$S=\frac{R e^{-\lambda t d}}{\mathrm{~A}}\left(1-e^{-t i r}\right)\left(1-e^{-t r e a l}\right) R$

The concentration of the metals in the samples is determined by the comparator method using equal weights of both sample and standard, with the same irradiation, decay and counting times. 


\section{Statistical Analysis}

The concentration of elements in dust samples were analyzed using SPSS 17.0 software while charts were drawn using Microsoft excel 2007.

\section{Results and Discussion}

The analysis of metals in cement factory and Kiln Feed dusts showed the presence of 29 elements in Cement factory dust while Kiln Feed dust showed 31 elements. Out of the 29 elements found in cement dust, 17 are major and minor elements, 9 rare earth, and 3 natural radionuclide (U, Th, K) elements. Earlier, Kpeglo, et al., (2012) reported 10 major, 4 rare earth , and three natural radionuclide (U, Th, K) elements in Ghanian cements. The mean elemental concentrations in cement dust was $\mathrm{Mg}(3425.50 \mathrm{mg} / \mathrm{kg}), \mathrm{Al}(29780.00 \mathrm{mg} / \mathrm{Kg}), \mathrm{Ca}$ (482250.00 mg/Kg), Ti (1409.50 mg/Kg), V (30.35 mg/Kg), Mn (1306.00 mg/Kg), Dy (3.08 mg/Kg), Na (580.67 mg/Kg), K (8705.00 mg/Kg), As (3.85 mg/Kg), Br (0.56 mg/Kg), La (42.47 mg/Kg), Sm (6.13 mg/Kg), Ho $(0.45 \mathrm{mg} / \mathrm{Kg}), \mathrm{U}(1.89 \mathrm{mg} / \mathrm{Kg}), \mathrm{Sc}(4.82 \mathrm{mg} / \mathrm{Kg}), \mathrm{Cr}(47.40 \mathrm{mg} / \mathrm{Kg}), \mathrm{Fe}(25903.33 \mathrm{mg} / \mathrm{Kg}), \mathrm{Co}(8.23$ $\mathrm{mg} / \mathrm{Kg}), \mathrm{Zn}(26.85 \mathrm{mg} / \mathrm{Kg}), \mathrm{Rb}(53.03 \mathrm{mg} / \mathrm{Kg}), \mathrm{Cs}(2.40 \mathrm{mg} / \mathrm{Kg}), \mathrm{Ba}(239.33 \mathrm{mg} / \mathrm{Kg}), \mathrm{Nd}(39.93 \mathrm{mg} / \mathrm{Kg}), \mathrm{Eu}$ $(1.13 \mathrm{mg} / \mathrm{Kg}), \mathrm{Yb}(1.50 \mathrm{mg} / \mathrm{Kg}), \mathrm{Lu}(0.22 \mathrm{mg} / \mathrm{Kg}), \mathrm{Hf}(3.89 \mathrm{mg} / \mathrm{Kg})$, and Th $(10.24 \mathrm{mg} / \mathrm{Kg})$. The Kiln Feed dust showed the presence of $\mathrm{Mg}(1702.00 \mathrm{mg} / \mathrm{kg}), \mathrm{Al}(23193.33 \mathrm{mg} / \mathrm{Kg}), \mathrm{Ca}(362500.00 \mathrm{mg} / \mathrm{Kg}), \mathrm{Ti}(1295.67$ $\mathrm{mg} / \mathrm{Kg}), \mathrm{V}(19.63 \mathrm{mg} / \mathrm{Kg}), \mathrm{Mn}(1028.33 \mathrm{mg} / \mathrm{Kg})$, Dy $(2.48 \mathrm{mg} / \mathrm{Kg}), \mathrm{Na}(435.33 \mathrm{mg} / \mathrm{Kg}), \mathrm{K}(7090.33 \mathrm{mg} / \mathrm{Kg})$, As $(2.80 \mathrm{mg} / \mathrm{Kg}), \mathrm{Br}(17.87 \mathrm{mg} / \mathrm{Kg}), \mathrm{La}(29.67 \mathrm{mg} / \mathrm{Kg}), \mathrm{Sm}(4.13 \mathrm{mg} / \mathrm{Kg})$, Ho (0.61 mg/Kg), U (1.37 mg/Kg), Sc (3.68 mg/Kg), Cr (21.97 mg/Kg), Fe (14693.33 mg/Kg), Co (5.31 mg/Kg), Zn (24.97 mg/Kg), Rb (62.5 $\mathrm{mg} / \mathrm{Kg}), \mathrm{Sb}(0.26 \mathrm{mg} / \mathrm{Kg}) \mathrm{Cs}(3.68 \mathrm{mg} / \mathrm{Kg}), \mathrm{Ba}(154.00 \mathrm{mg} / \mathrm{Kg}), \mathrm{Nd}(33.53 \mathrm{mg} / \mathrm{Kg}), \mathrm{Eu}(0.88 \mathrm{mg} / \mathrm{Kg}), \mathrm{Yb}(0.95$ $\mathrm{mg} / \mathrm{Kg}), \mathrm{Lu}(0.13 \mathrm{mg} / \mathrm{Kg})$, Hf $(2.21 \mathrm{mg} / \mathrm{Kg}), \mathrm{Hg}(0.26 \mathrm{mg} / \mathrm{Kg})$ and $\mathrm{Th}(7.05 \mathrm{mg} / \mathrm{Kg})$. The elemental contents were the same in both dust samples except for the presence of Mercury and Antimony in each of the triplicate samples of Kiln feed which was not found in the cement dust. The elemental contents in the cement dust were within some varying range of concentrations, for $\mathrm{Mg}(2690.00-4161.00 \mathrm{mg} / \mathrm{kg})$, Al (29540.00 - 30020.00 $\mathrm{mg} / \mathrm{Kg}), \mathrm{Ca}(465300.00-499200.00 \mathrm{mg} / \mathrm{Kg})$, Ti $(1321.00-1498.00 \mathrm{mg} / \mathrm{Kg}), \mathrm{V}(29.30-31.40 \mathrm{mg} / \mathrm{Kg}), \mathrm{Mn}$ (1302.00 $1310.00 \mathrm{mg} / \mathrm{Kg})$, Dy $(2.51-3.65 \mathrm{mg} / \mathrm{Kg}), \mathrm{Na}(562.00-592.00 \mathrm{mg} / \mathrm{Kg}), \mathrm{K}(8143.00-9478 \mathrm{mg} / \mathrm{Kg})$, As $(3.59-4.06 \mathrm{mg} / \mathrm{Kg}), \mathrm{Br}(0.00-0.56 \mathrm{mg} / \mathrm{Kg}), \mathrm{La}(41.70-43.60 \mathrm{mg} / \mathrm{Kg}), \mathrm{Sm}(5.72-6.65 \mathrm{mg} / \mathrm{Kg}), \mathrm{Ho}(0.33-$ $0.54 \mathrm{mg} / \mathrm{Kg}), \mathrm{U}(1.65-2.06 \mathrm{mg} / \mathrm{Kg}), \mathrm{Sc}(4.39-5.07 \mathrm{mg} / \mathrm{Kg}), \mathrm{Cr}(43.50-49.90 \mathrm{mg} / \mathrm{Kg}), \mathrm{Fe}(20040.00-$ $35770.00 \mathrm{mg} / \mathrm{Kg})$, Co $(8.17-8.28 \mathrm{mg} / \mathrm{Kg}), \mathrm{Zn}(26.20-27.50 \mathrm{mg} / \mathrm{Kg}), \mathrm{Rb}(40.90-61.70 \mathrm{mg} / \mathrm{Kg})$, Cs $(2.02-$ $2.78 \mathrm{mg} / \mathrm{Kg}), \mathrm{Ba}(230.00-247.00 \mathrm{mg} / \mathrm{Kg}), \mathrm{Nd}(36.40-42.60 \mathrm{mg} / \mathrm{Kg}), \mathrm{Eu}(1.03-1.24 \mathrm{mg} / \mathrm{Kg}), \mathrm{Yb}(1.42-$ $1.61 \mathrm{mg} / \mathrm{Kg})$, Lu $(0.21-0.22 \mathrm{mg} / \mathrm{Kg})$, Hf $(3.68-4.07 \mathrm{mg} / \mathrm{Kg})$, and Th $(9.63-10.90 \mathrm{mg} / \mathrm{Kg})$. The Feed dust showed the following range of elemental concentration as $\mathrm{Mg}(0.00-1702.00 \mathrm{mg} / \mathrm{kg}), \mathrm{Al}(3940.00-21040.00$ $\mathrm{mg} / \mathrm{Kg}), \mathrm{Ca}(313700.00-394500.00 \mathrm{mg} / \mathrm{Kg})$, Ti $(1119.00-1460.00 \mathrm{mg} / \mathrm{Kg}), \mathrm{V}(17.10-23.40 \mathrm{mg} / \mathrm{Kg}), \mathrm{Mn}$ (947.00 1094.00 mg/Kg), Dy (2.21 - $2.70 \mathrm{mg} / \mathrm{Kg}), \mathrm{Na}(402.00-7952.00 \mathrm{mg} / \mathrm{Kg}), \mathrm{K}(5625.00-7952 \mathrm{mg} / \mathrm{Kg})$, As $(2.44-3.13 \mathrm{mg} / \mathrm{Kg}), \mathrm{Br}(8.92-30.40 \mathrm{mg} / \mathrm{Kg}), \mathrm{La}(29.10-30.40 \mathrm{mg} / \mathrm{Kg}), \mathrm{Sm}(3.98-4.35 \mathrm{mg} / \mathrm{Kg}), \mathrm{Ho}(0.24$ - $0.97 \mathrm{mg} / \mathrm{Kg}), \mathrm{U}(1.21-1.58 \mathrm{mg} / \mathrm{Kg}), \mathrm{Sc}(3.61-3.78 \mathrm{mg} / \mathrm{Kg}), \mathrm{Cr}(20.40-23.40 \mathrm{mg} / \mathrm{Kg})$, Fe $(14220.00-$ $15060.00 \mathrm{mg} / \mathrm{Kg})$, Co $(5.20-5.39 \mathrm{mg} / \mathrm{Kg}), \mathrm{Zn}(20.80-30.20 \mathrm{mg} / \mathrm{Kg}), \mathrm{Rb}(54.70-68.10 \mathrm{mg} / \mathrm{Kg}), \mathrm{Sb}(0.00-$ $0.26 \mathrm{mg} / \mathrm{Kg}) \mathrm{Cs}(3.12-4.24 \mathrm{mg} / \mathrm{Kg}), \mathrm{Ba}(110.00-176.00 \mathrm{mg} / \mathrm{Kg}), \mathrm{Nd}(29.90-36.60 \mathrm{mg} / \mathrm{Kg}), \mathrm{Eu}(0.82-0.92$ $\mathrm{mg} / \mathrm{Kg}), \mathrm{Yb}(0.85-1.03 \mathrm{mg} / \mathrm{Kg}), \mathrm{Lu}(0.12-0.15 \mathrm{mg} / \mathrm{Kg}), \mathrm{Hf}(1.32-3.11 \mathrm{mg} / \mathrm{Kg}), \mathrm{Hg}(0.00-0.26 \mathrm{mg} / \mathrm{Kg})$ and $\mathrm{Th}(6.61-7.72 \mathrm{mg} / \mathrm{Kg})$. The order of elemental concentration in both dusts is $\mathrm{Ca}>\mathrm{Al}>\mathrm{Fe}>\mathrm{K}>\mathrm{Mg}>\mathrm{Ti}>$ $\mathrm{Mn}>\mathrm{Na}>\mathrm{Ba}>\mathrm{Rb}>\mathrm{Rb}>\mathrm{Cr}>\mathrm{La}>\mathrm{Nd}>\mathrm{V}>\mathrm{Zn}>\mathrm{Th}>\mathrm{Co}>\mathrm{Sm}>\mathrm{Sc}>\mathrm{Hf}>\mathrm{As}>\mathrm{Dy}>\mathrm{Cs}>\mathrm{U}>\mathrm{Yb}>\mathrm{Eu}$ $>\mathrm{Br}>\mathrm{Ho}>\mathrm{Lu}>\mathrm{Hg}=\mathrm{Sb}$. Comparison of the elemental contents in the two dusts type (Fig. $2-4$ ) indicated cement dust to contain higher concentrations of the elements. The presence of these elements in the cement factory dust is dependent on both the primary raw materials (calcium carbonate in the form of chalk or limestone, and alumina and silica in the form of clay or shale) and secondary raw materials (Gypsum, phosphogypsum, pozzolanas, fly ash, blast furnace slag, iron oxide, and spent catalysts), and fuel (coal, petroleum coke, used oil, and scrap tires) used in the manufacturing of the cement. These assertions agree with the Feed dust elemental constituents which is a mirror image of the cement dust. The absence of $\mathrm{Hg}$ and $\mathrm{Sb}$ suggest a possible volatility of these elements during calcination of the raw materials. 


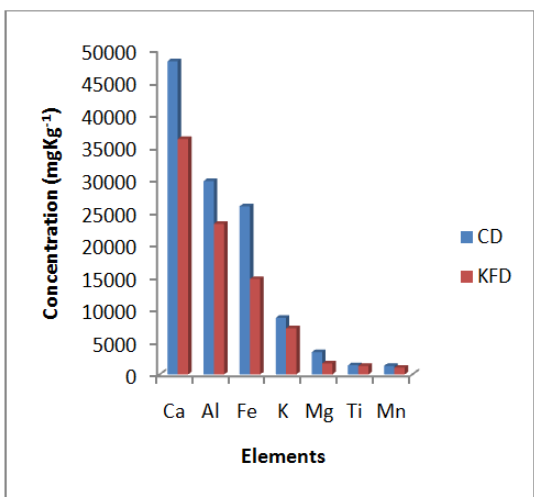

Fig. 2: Distribution of major elements in kiln feed (KFD) and cement dusts (CD)

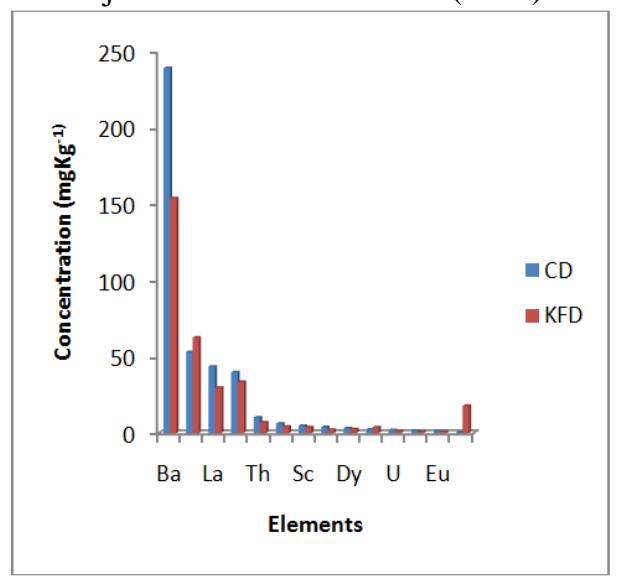

Fig. 3: Distribution of rare Earth and other elements in Kiln feed (KFD) and Cement dusts (CD)

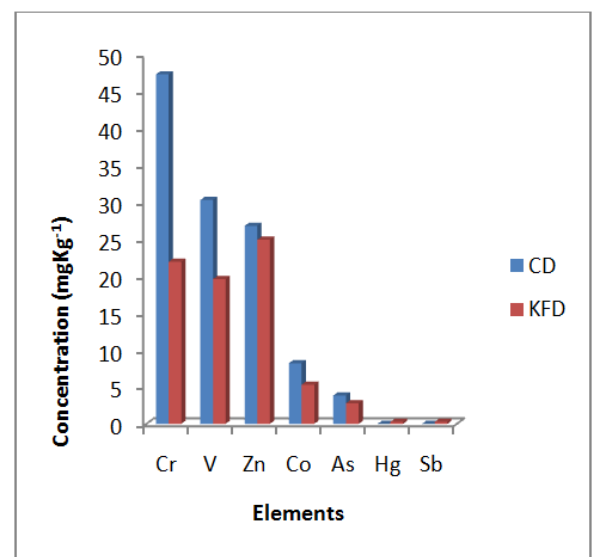

Fig. 4: Distribution of toxic metals in kiln feed (KFD) and cement dusts (CD)

Portland cement dusts have been reported to be a source of environmental pollutants with a well defined toxic pathology (Kpeglo, et al., 2012). Especially known are the toxic effects of arsenic, and mercury (Domingo, 1994; Chang, 1996). Aluminium, chromium, manganese and zinc, among others, have been also identified in the emissions from cement plants. While some of these elements are essential for humans, at high levels they can also be a toxicological risk (Domingo, 1994; Chang, 1996). Some elements are very important for environmental pollution control because of their potential toxicity. Dust from the manufacturing of cement and subsequent inhalation or ingestion by occupational staff or residents scattered around the industry is inevitable and hence metal toxicants in these dusts may constitute potential health risk. These are because; the effects of exposure to any hazardous substance depend on the route of the exposure (skin, inhalation, and ingestion), how long the exposure lasts, and how high the exposure is. In any person, the effects also depend on the person's health history, personal traits and habits, and whether other chemicals are present (Kpeglo, et al., 2012). The level of toxicity found may not be problem in the short term but in the long term it may raise concerns. Bivariate Pearson correlation analysis for the major elemental concentration of cement factory dust 
and Kiln feed dust using SPSS statistic 17.0 soft ware shows that there is positive correlation at $99 \%$ confidence (2-tailed) for calcium, Titanium,, Vanadium, Cobalt, Dysprosium and Holmium, while it is negative for $\mathrm{Al}$ and Mn This suggests the dependence of cement elemental constituents on the kiln feed for the correlated elements, indicating that the source of these elements might be the raw material.

The continuous inhalation or ingestion of the metal laden dust makes even the smallest concentration of such elements, some of which are toxic, a concern to the health of occupational staff or residents scattered around the industry. This work reveals that the cement work environment could be loaded with elements that may constitute a problem to the health of occupational staff and other residents in the vicinity of the factory.

\section{References}

[1]. Addo, M. A., E.O. Darko, C. Gordon, B. J. B. Nyarko, J. K. Gbadago, E. Nyarko, H. A. Affum, B. O. Botwe (2012) Evaluation of Heavy Metals Contamination of Soil and Vegetation in the Vicinity of a Cement Factory in the Volta Region, Ghana. International Journal of Science and Technology 2(1), 40-50

[2]. Aidid, S. B. (1988). Determination of trace elements in leaves of tropical trees in Malaysia by neutron activation analysis. J. RadioanalNucl. Chem. Art. 120, 335 - 344.

[3]. Ali-Abdulla, M., N.A.Mansour, M.A.Ali, M. Fayez-Hassan (2011) Neutron Activation Analysis of Cement Bulk Samples; Adv. Appl. Sci. Res., 2011, 2 (4):613-620

[4]. Amira Cipurkovic, IlvanaTrumic, ZoricaHodžic, VahidaSelimbašic and Abdel Djozic 2014 Distribution of heavy metals in Portland cement production process. Adv. Appl. Sci. Res., 2014, 5(6): 252-259

[5]. Andrej, J. (1987). Bees and their products as indicators of environmental pollution. Med. Weter. 43 (6), 353 - 356.

[6]. Bar-Ziv, J. and Golberg, G. M. (1974). Simple siliceous pneumoconiosis in Negev, Bendouins. Archives of Environ Health. 29, 121 $-126$.

[7]. Chang, L. W. (1996) "Toxicology of Metals" CRC Lewis Publishers, Boca Raton, FL, USA

[8]. Cristache Carmen, Octavian G. Duliu, CalinRicman, Magdalena Toma, Felicia Dragolici, MihaelaBragea, Laurentiu Done (2008)Determination Of Elemental Content In Geological Samples. Rom. Journ. Phys., Vol. 53, Nos. 7-8, P. 941-946

[9]. Domingo, J. L. (1994) "Metal-induced developmental toxicity in mammals: a review" J Toxicological Environment and Health, 42, 123-141

[10]. Ehmann, E.D, Yates, (1986) Nucl. and Radio- chemical analysis, Anal. Chemistry 49 R 65 R.

[11]. Farmer, A.M., (1993). The effects of dust on vegetation a review. Environ. Poll. (79), 63-75.

[12]. Fatima, S. K., P. A. Prabhavathi, P. Padmavathi and P. P. Reddy (2001).Analysis of chromosomal aberrations in men occupationally exposed to cement dust. Mutation Research/Genetic Toxicology and Environmental Mutagenesis 490(2): 179-86.

[13]. Gladney, E. S .,B. T. O'Malley, J. Roelandts and T. E. Gills, (1987)Natl. Bu. Stds @ TIST Spec. Pub., 260-1 1,

[14]. Hailu Awoke Taddesse, A.K. Chaubey, AsresYehunieHibstie (2013) Investigation of Traffic air Pollution in Addis Ababa City around Selected Bus Stations Using Instrumental Neutron Activation Technique International Journal of Basic and Applied Science Vol. 01, No. 03, Jan 2013, pp. 613-620

[15]. Hirano, T., Kiyota, M. T. and Aiga, I. (1995). Physical effects of dust on leaf (1995) physiology of Cucumber and kidney bean plants. J. Environ Poll. 89 (3); 255 - 261.

[16]. IAEA (1998) Use of Research Reactors for Neutron Activation Analysis, advisory group, IAEA TECDOC 1215, Vienna, 22-26 June

[17]. Ibrahim, H. H., U.A. Birnin-Yauri, C. Muhammad and A. Uma (2012) Assessment of Pollution Potentialities of some Portland Cement Nigerian Journal of Basic and Applied Science (June, 2012), 20(2): 182-184

[18]. Janghorbani, M ., B. T. G. Ting and V. R. Young, Adv. Nutr. Res. 3,127 (1980).

[19]. Kafala S. I., Macmahon T. D (2007).;. Radioanl.Nucl. Chem., , 271(2) 507.

[20]. Kolesov G. M and Shubina N. A. (2003) g. of Analyt. Chem. 58, 307.

[21]. Kpeglo, D.O., H. Lawluvi, A. Faanu, A.R. Awudu, C.C. Arwui, P. Deatanyah, S. Wotorchi-Gordon, E.O. Darko, G. Emi-Reynolds, N.S. Opata and I.K. Baidoo (2012) Radiochemical Pollutants Concentration in Ghanaian Cement by Instrumental Neutron Activation Analysis and X-Ray Spectrometry. Research Journal of Environmental and Earth Sciences 4(1): 99-104,

[22]. Kusaka, Y., Yokoyama, Y. Sera, Y., Yamamoto, S., Sone, S. Kyono, H. Shirakawa, T. and Goto, S. (1986). Impact of air pollution on plants and animals. J. Environ. Manag. Health. 4,21 - 25

[23]. Levi H., (1996) Semi centennial lecture, addendum to the proceedings of 7 th inter. conference of modern trends in the activation analysis, Copenhagen, Denmark, 1996 June 23-27

[24]. Ni, B. F., P. Wang, Y. Luo and S. Yu. J. (1991).Radioanal. Nucl. Chem.. 151, 255

[25]. Nigeria Stock Exchange, NSE (2004). Investors guide: The cement industry in Nigeria. http://www.pangaeapartners.com/nigjuly/.htm (accessed, April, 2004).

[26]. Niragau, J.O., Davidson, C.L., 1986. Toxic Metals in the Atmosphere. John Wiley and Sons, New York.

[27]. Nsi, E. W. and shallsuku, P. (2002). Industrial pollution; A case study of dust pollution from a cement industry. J. Chem. Nig., 27, 2002.

[28]. Olowoyo, Joshua Oluwole, Liziwe L. Mugivhisa, Nomsa G. Busa (2015) Trace Metals in Soil and Plants around a Cement Factory in Pretoria, South Africa. Pol. J. Environ. Stud. Vol. 24, No. 5 (2015), 2087-2093

[29]. Volkavic, V. (1975). Trace element analysis. Taylor and Francis Ltd, London, pp 57 - 81.

[30]. Warrell, A. D., Harrison, B. D. W., Fawcett, I. W., Mohammed, W. S., Pope, H. M. and Watkins, B. J. (1975). A microfocus of silicosis among sandstone quarries near Danbatta, Kano State, Nigeria. Savanna. 4 (1), 1 - 11.

[31]. Winder C. and Carmody M. (2002) The dermal toxicity of cement of cement.Toxicol. Ind. Health, 18, 321- 331

[32]. Win, D. T. (2004) Neutron Activation Analysis (NAA) AU J.T. 8(1): 8-14

[33]. Wufem, M. Buba 1*, Ibrahim2, A. Q, Maina3 M. Humphrey., Nangbes, J. Gungsat 1, John, B. Nvau (2013) Speciation of Some Heavy Metals in Soils around A Cement Factory In Gombe State, Nigeria. The International Journal Of Engineering And Science, IJES, Vol.2, Issue 9,110-115.

[34]. Yoshiaki, I, Kaoru, O. and Igakuto, S. (1986). Metal pollution from automotive emissions and its effects on plants and animals. Environ. Sci. Technol. 11, 17 - 20.

[35]. Zeleke, Z., B. Moen and M. Bratveit (2010). Cement dust exposure and acute lung function:A cross shift study. BMC Pulmonary Medicine 10(1):19

DOI: $10.9790 / 2402-1008010813$

Page

www.iosrjournals.org 
